\title{
Vitellogenesis and choriogenesis in fishes
}

\author{
Akihiko Hara $^{1}$. Naoshi Hiramatsu ${ }^{1}$ Toshiaki Fujita ${ }^{2}$
}

Received: 5 March 2015 / Accepted: 10 December 2015 / Published online: 23 January 2016

(c) The Author(s) 2016. This article is published with open access at Springerlink.com

\begin{abstract}
In studies of sex discrimination in fish in the early 1900s, a specific antigen in the blood of gravid females was identified using immunological methods. At present, this specific antigen is known as vitellogenin, the major precursor of egg yolk protein that is synthesized in the female liver and is secreted into the blood to be incorporated into the egg. Recently, protein and gene analyses have revealed the presence of several vitellogenin variants. In addition, in the 1980s, choriogenin was identified as a novel precursor of egg envelope proteins that is secreted into the blood in response to stimulation by estrogen, similarly to vitellogenin. These two proteins not only play key roles in the process of oogenesis, but they are also used as effective biomarkers for assessing the impact of estrogenlike endocrine-disrupting chemicals (environmental hormones) in aquatic ecosystems.
\end{abstract}

Keywords Vitellogenin - Choriogenin - Yolk protein . Estrogen · Biomarker - Endocrine disrupting chemicals . Fish

This article publication was supported by the Japan Society for the Promotion of Science (JSPS) in a Grant-in-Aid for Publication of Scientific Research Results (KAKENHI 262003).

Akihiko Hara

aki@fish.hokudai.ac.jp

Naoshi Hiramatsu

naoshi@fish.hokudai.ac.jp

Toshiaki Fujita

t-fujita@hi-teck.ac.jp

1 Faculty of Fisheries Sciences, Hokkaido University, Hakodate, Hokkaido 041-8611, Japan

2 Faculty of Engineering, Hachinohe Institute of Technology, Hachinohe, Aomori 031-8501, Japan

\section{Introduction}

The presence of a protein specifically found in female blood serum during oocyte growth in fishes was first reported in 1914 by Uhlenhuth and Kodama [1] in a paper entitled 'A study of sexual distinction reaction'. In this study, the authors used an immunological method (precipitation reaction) with antisera from rabbits immunized with carp Cyprinus carpio egg extract to detect a substance reactive with this antisera in the blood of carp carrying mature eggs. They named this substance ovumin. Later, in 1923, Sakuma [2] reported in his paper entitled 'On the precipitin reaction of the reproductive cells and the sexual differences' that he studied sexual differences in 14 marine fish species using a similar method and found that antisera against fish eggs indeed, as observed in the case of carp, reacted with blood serum from mature females.

In the 1940s, using the Tiselius method of electrophoresis, Deutsch et al. [3, 4] and Moore [5] analyzed the electrophoretic patterns of serum proteins from several fish species and reported species differences. In addition, in 1957, Saito [6, 7] used the Tiselius method along with paper electrophoresis, and reported on the existence of both qualitative and quantitative characteristic differences in serum proteins between teleosts and elasmobranchs, that also depended upon fish habitat. Later, fish serum proteins became widely used as biochemical tools among researchers in various fields such as taxonomy, genetics, physiology and biochemistry (review in Hara [8]: see references therein).

Since 1961, the presence of proteins specifically expressed in the blood of maturing females (serum vitelline [9], Sm antigen [10], HM factor [11], serum lipovitellin [12], FSPP [13], lipophosphoprotein [14]) has been 
observed in many fish species using various analytical methods, including newly developed variations of electrophoresis, gel-filtration, ion-exchange chromatography, ultracentrifugation and immunological methods. We also discovered a female-specific iron-binding serum protein (FS) in rainbow trout Oncorhynchus mykiss and chum salmon $O$. keta [15] while analyzing interspecies differences in electrophoretic patterns of serum proteins. In 1969 , in the field of entomology, such female-specific proteins expressed in the blood (body fluid) during oogenesis were named 'vitellogenin (Vtg)' (vitelline + genin, meaning source of egg yolk) [16], and the name has been used ever since for proteins specifically expressed in the blood of maturing females in oviparous vertebrates. In general, Vtg in oviparous vertebrates is a lipoglycophosphoprotein and serves as a major precursor of egg yolk proteins stored as essential nutrients for future embryogenesis. The process or period in which this Vtg-derived egg yolk accumulates within oocytes is called vitellogenesis. During this process, estrogen secreted from the ovarian follicles triggers the synthesis of Vtg in the liver, which is then secreted into the blood, incorporated into oocytes and cleaved to generate multiple egg yolk proteins such as lipovitellin (Lv) and phosvitin $(\mathrm{Pv})$ that will be stored in the ooplasm (reviews in Wallace [17], Mommsen and Walsh [18], Selman and Wallace [19], Specker and Sullivan [20], Hiramatsu et al. [21, 22], Patiño and Sullivan [23], Reading and Sullivan [24]).

In the 1970s, multiple female-specific serum proteins were reported by Plack et al. [25] and Aida et al. [13] in Atlantic cod Gadus morhua and ayu Plecoglossus altivelis, respectively. We also detected three female-specific serum proteins components in medaka Oryzias latipes [26], and four to five components in white-edged rockfish Sebastes taczanowskii [27]. In the era from the 1970s to the 1990s, the presence of female-specific serum proteins other than $\mathrm{Vtg}$ was shown. Some of these proteins were expressed prior to the main phase of yolk deposition, indicating the possibility that they differed from $\mathrm{Vtg}[13,27,28]$.

An estrogen-inducible female-specific protein different from Vtg with a relatively small molecular weight was discovered in 1984 in medaka, and was later revealed to be the precursor of egg envelope protein [29]. This substance was named 'choriogenin (Chg)' (chorion + genin, meaning 'source of egg envelope') [30]. Similar to Vtg, Chg is an estrogen-induced maternal protein that functions as an oogenic protein forming the inner layer of the egg envelope.

Since the mid-1990s, Vtg has attracted attention as a biomarker for evaluating the effects of endocrine systemdisrupting chemicals present in various waters. Environmental induction of Vtg was first reported in male rainbow trout stocked near a wastewater treatment plant in the UK [31]. Later, many studies linking Vtg expression with estrogenic-like endocrine disrupting chemicals (EEDCs) were reported mainly from Europe and North America (reviews; Sumpter [32], Arcand-Hoy and Benson [33], Giesy and Snyder [34], Kime [35], Pait and Nelson [36], Arukwe and Goksøyr [37], Hiramatsu et al. [22]).

Over time, we acquired basic knowledge about Vtg in fish and established various immunoassays to detect the compound. Our laboratory has also conducted studies of Chg, mainly using Salmonidae species and focusing on estrogen-induction ('choriogenesis'), because this protein is a key biomarker for assessing EEDCs. Here, we review our studies on Vtg and Chg in fish and discuss some recent developments on this topic.

\section{Fish vitellogenin and its related egg yolk proteins}

Chicken oogenesis has been studied since the beginning of the 1900s, when oocyte growth was attributed to the uptake of low-molecular-weight substances such as amino acids, which were thought to be responsible for forming egg yolk proteins. A new idea that egg yolk proteins are first synthesized in the maternal liver and then transferred to growing oocytes via the blood was proposed, and it was first proven in 1974 that Vtg was the precursor of egg yolk proteins based upon a biochemical study using African clawed frogs Xenopus laevis [38]. In this study, Vtg double-labeled with ${ }^{3} \mathrm{H}$ and ${ }^{32} \mathrm{P}$ was taken up by eggs after the administration of estrogen and cleaved into two egg yolk proteins with different molecular weights: $\mathrm{Lv}$ with ${ }^{3} \mathrm{H}$ radioactivity and $\mathrm{Pv}$ with ${ }^{3} \mathrm{H}$ and ${ }^{32} \mathrm{P}$ activity. This transformation from Vtg to egg yolk proteins was also demonstrated in chickens Gallus domesticus, using a similar method [39].

During the study of fish species, we isolated and purified $\mathrm{Vtg}$ and three egg yolk proteins, $\mathrm{Lv}, \mathrm{Pv}$ and $\beta^{\prime}$-component $\left(\beta^{\prime}-c\right)$, from fish in the family Salmonidae, including rainbow trout [40] and Sakhalin taimen Hucho perryi [41]. Using various antibodies against the purified proteins along with immunodiffusion and Western blotting methods, we visualized molecular cleavage of $\mathrm{Vtg}$ to produce $\mathrm{Lv}, \mathrm{Pv}$ and $\beta^{\prime}$-c. In the Sakhalin taimen, Vtg is a $540 \mathrm{kDa}$ dimer consisting of two $240 \mathrm{kDa}$ subunits containing $330 \mathrm{kDa} \mathrm{Lv}$ composed of two heavy-chains $(92 \mathrm{kDa})$ and two light-chains ( $29 \mathrm{kDa})$, $34 \mathrm{kDa} \beta^{\prime}-\mathrm{c}$ protein composed of a $17 \mathrm{kDa}$ peptide, and $23 \mathrm{kDa} \mathrm{Pv}$. Using biotin-labeled Vtg, we also observed its degradation into egg yolk proteins by bovine cathepsin D, suggesting specific degradation of Vtg in eggs by a cathepsin D-like enzyme [42, 43]. On the other hand, with regard to specific uptake of Vtg into eggs, a Vtg receptor was discovered, leading to the conclusion that the Lv domain within the Vtg molecule serves as a receptor-binding site [44].

For the purification of fish Vtg, we established a novel method in 1978 using rainbow trout by precipitating the 
serum of vitellogenic females under low ionic strength conditions (cold distilled water) and immediately loading samples onto a gel filtration column for isolation [40]. This simple and quick procedure is suitable for $\mathrm{Vtg}$, which is prone to degradation during the purification process. We also developed another purification method for proteins that are difficult to precipitate or for Vtg isolation from other fish species by using hydroxylapatite chromatography [45]. Many other methods such as ion-exchange chromatography have been used to purify Vtg from various fish, including rainbow trout [46], Atlantic salmon Salmo salar [47], goldfish Carassius auratus [48, 49], Japanese eel Anguilla japonica [50], catfish Heteropneustes fossilis [51], mummichog Fundulus heteroclitus [52] and coho salmon Oncorhynchus kisutch [53, 54] (review in Specker and Sullivan [20]).

$\mathrm{Lv}$, a major degradation product of $\mathrm{Vtg}$, is the main component of egg yolk, and its lipid content is about $20 \%$ by mass. In structure, $\mathrm{Lv}$ is a dimer consisting of two different polypeptides, a heavy chain $(\mathrm{LvH})$ and a light chain ( $\mathrm{LvL}$ ). $\mathrm{Lv}$ is abundant in various types of amino acids and lipids that are essential nutritional sources for embryogenesis. In contrast, $\mathrm{Pv}$ is a phosphoprotein with approximately $10 \%$ phosphorus and with serine (Ser) occupying $50 \%$ of the amino acid content, making Pv difficult to detect with normal staining techniques, and giving it extremely weak antigenicity because of its high phosphorus content. Minerals bound to the Ser residues in this phosphoprotein are thought to be essential components for osteogenesis and metabolic functions. The third component of the egg yolk protein, $\beta^{\prime}$-c, which is devoid of any lipid and phosphorus, was discovered in the rainbow trout by Jared and Wallace [55], and identified as a kind of serum protein. Later, Markert and Vanstone [56] isolated a similar protein from the eggs of coho salmon and named the protein $\beta^{\prime}$-c. It has also been isolated from fish other than salmonids, including barfin flounder Verasper moseri [57], white perch Morone americana [58] and grey mullet Mugil cephalus [59]. $\beta^{\prime}$-c is thus considered to be a ubiquitous egg yolk protein in teleosts. In the elasmobranch, we reported for the first time that $\beta^{\prime}$-c is also present in the eggs of cloudy catshark Scyliorhinus torazame [60]. Most of its function remains unclear, other than being a source of amino acids necessary in embryogenesis, but $\beta^{\prime}-\mathrm{c}$ contains large amounts of cysteine (Cys) residues within the molecule. Recently, Shimizu et al. [61] discovered that $\beta^{\prime}-\mathrm{c}$ is one of the allergens that cause fish egg allergy symptoms. Similarly, $40 \mathrm{kDa}$ glycoprotein (YG40) containing abundant Cys residues was found in chicken eggs [62], corresponding to fish $\beta^{\prime}$-c. Recently, from a study of the barfin flounder, the fourth egg yolk protein component considered to have originated from the furthest C-terminus of the $\mathrm{Vtg}$ polypeptide (C-terminal coding domain) was found [63]. Based on these results, the molecular sequence of the egg yolk proteins in Vtg is considered to be expressed, from the $\mathrm{N}$-terminus, as $\mathrm{NH}_{2}-(\mathrm{LvH})-(\mathrm{Pv})-(\mathrm{LvL})-\left(\beta^{\prime}-\mathrm{c}\right)-(\mathrm{C}$-terminal coding domain)-COOH (see Fig. 2) [21, 22, 64-66].

\section{Vitellogenesis in fish}

The general characteristics of Vtg in oviparous vertebrates can be summarized as follows: (1) Vtg is a protein specifically expressed in female blood serum during vitellogenesis; (2) The administration of estrogen to male or juvenile fish induces the production of plasma Vtg; (3) Vtg is a high-molecular-mass complex protein consisting of sugar, lipid and phosphorus and binding other elements such as calcium, iron and zinc; (4) Vtg is a precursor of egg yolk proteins that react with antibodies raised against egg extracts.

Figure 1 depicts an oogenesis model of Salmonidae involving Vtg and the substance Chg, which is described later. The process of vitellogenesis in fish is understood as follows: (1) Follicle-stimulating hormone (FSH) secreted into the bloodstream by the pituitary gland acts on follicle cells surrounding developing oocytes to induce synthesis of the sex steroid hormone, estrogen (estradiol-17 $\beta$ ), which induces vitellogenesis. The estrogen links to sex steroid hormone-binding globulin in the blood and is transferred to hepatocytes to act on the Vtg gene in the nucleus via estrogen receptors. The complex of estrogen and the estrogen receptor in hepatocytes binds to the promoter region of the Vtg gene, which activates the gene to initiate and accelerate transcription. (2) Then, translation of the Vtg transcript products begins, after which Vtg proteins undergo modification processes such as lipidation, phosphorylation and glycosylation before being secreted into the blood. (3) Blood Vtg binds to the Vtg receptor on the oocyte plasma membrane and is taken into the cell. (4) Vtg that enters an oocyte is degraded specifically by a cathepsin D-like enzyme and undergoes molecular cleavage to produce Lv, $\mathrm{Pv}$, and $\beta^{\prime}-\mathrm{c}$, which are stored in the cell. This is the 'single Vtg model', which was formerly proposed when Vtg was considered to be composed of a single molecular species of protein. However, as a result of the recent discovery of multiple species of Vtg, the 'multiple Vtg model' with more complex processes is now accepted as a more accurate description of vitellogenesis [22].

One of the most interesting features of $\mathrm{Vtg}$ is that, through exposure to estrogen, Vtg can be induced in systems where its synthesis would not normally occur, such as in male liver or in vitro liver tissue, and cultured hepatocytes. In general, Vtg can be detected in any culture system, regardless of fish species, when induced with $\geq 10^{-8} \mathrm{M}$ estradiol-17 $\beta$ [67]. In vivo Vtg induction studies using 


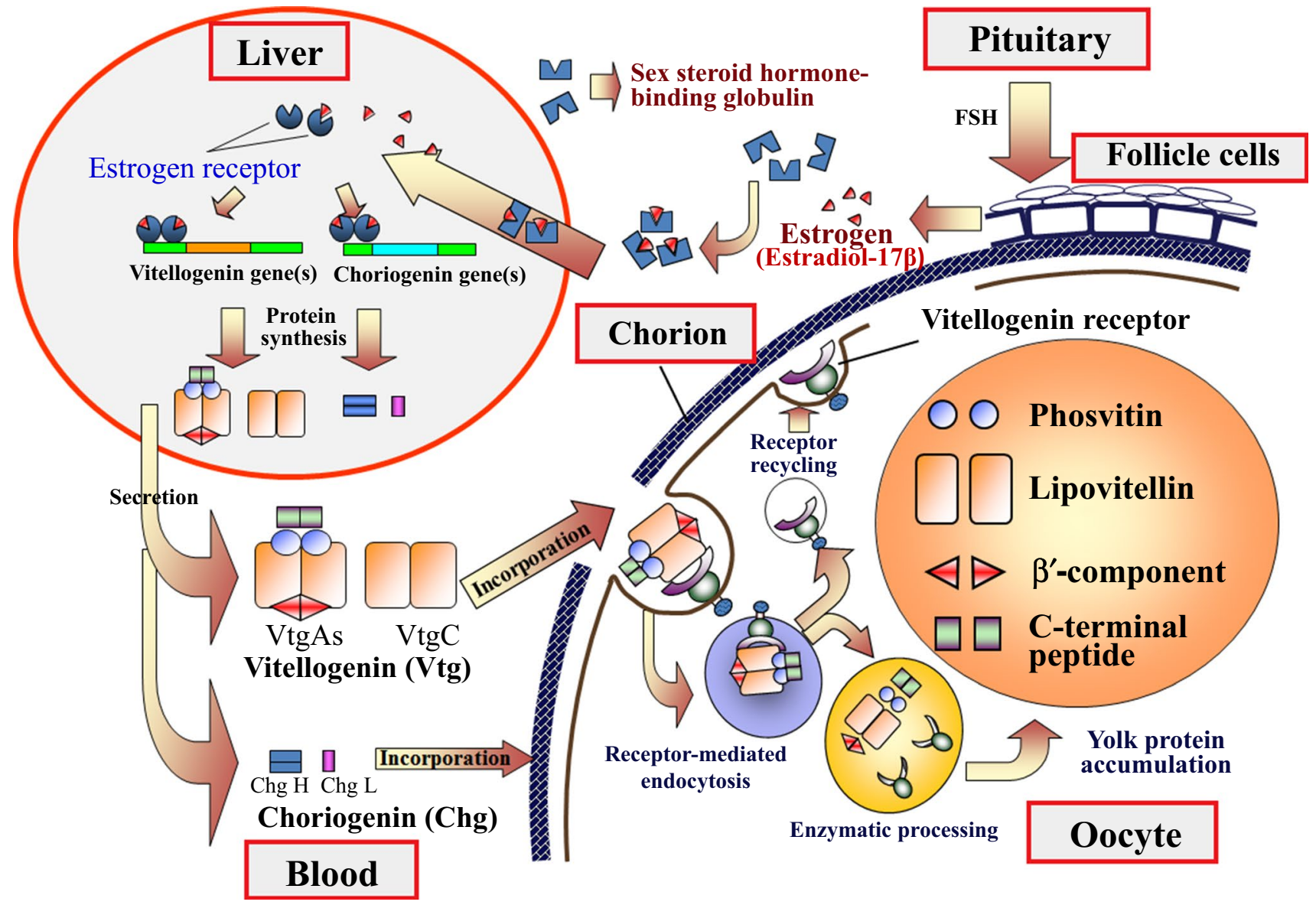

Fig. 1 Model of vitellogenesis and choriogenesis in salmonid fish. See text for details and abbreviations. Redrawn from Hiramatsu et al. [22]

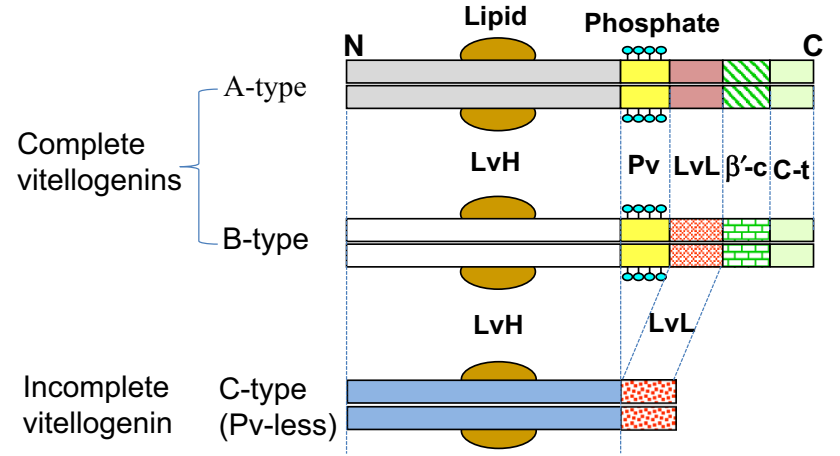

Fig. 2 Domain structures of fish vitellogenins with regard to their derived yolk protein products, lipovitellin $(\mathrm{Lv})$, phosvitin $(\mathrm{Pv})$, $\beta^{\prime}$-component $\left(\beta^{\prime}\right.$-c) and $\mathrm{C}$-terminal coding domain $(\mathrm{C}-\mathrm{t})$. Monomeric Lv is composed of two subunits: a heavy chain $(\mathrm{LvH})$ and a light chain $(\mathrm{LvL})$. This figure is reproduced from the one published in Hiramatsu et al. [66]

estrogen treatment have demonstrated that a single treatment with $10 \mu \mathrm{g}$ estradiol-17 $\beta / \mathrm{kg}$ body weight resulted in blood Vtg detection within $24 \mathrm{~h}$, regardless of fish species. The amount of induced Vtg in the blood reached the order of $\mu \mathrm{g} / \mathrm{ml}$ in $12 \mathrm{~h}$, depending upon conditions such as the dose of estradiol-17 $\beta$ and the water temperature. It has also been suggested that, judging from observations that Vtg was hardly detected in the blood when estradiol-17 $\beta$ was administered at concentrations less than $10 \mu \mathrm{g} / \mathrm{kg}$ body weight, even with multiple injections, there exists a certain threshold in the estrogen concentration required to induce Vtg synthesis.

The Vtg level also changes as fish progress through oogenesis. We observed an annual change in the Vtg level in Sakhalin taimen (Salmonidae), as measured by an enzyme linked immunosorbent assay and the Mancini method (mentioned later), demonstrating fluctuations in the blood Vtg concentration in accordance with fish maturation [68]. In pond cultures, female Sakhalin taimen generally become sexually mature and sufficiently gravid for egg collection within 6-7 years. In 3-year-old fish, the level of Vtg in blood serum ranges from 1 to $10 \mu \mathrm{g} / \mathrm{ml}$. As fish approach sexual maturity, Vtg levels gradually increase to $1 \mathrm{mg} / \mathrm{ml}$ in the year prior to egg collection, followed by a rapid increase reaching several tens of $\mathrm{mg} / \mathrm{ml}$ a few months prior to egg collection. As indicated by this study, blood 
serum levels of Vtg in females fluctuate over a relatively wide range (from $1 \mu \mathrm{g} / \mathrm{ml}$ to several tens of $\mathrm{mg} / \mathrm{ml}$ ), compared with those of other serum proteins.

As described above, Vtg is subjected to limited degradation during vitellogenesis to produce at least three types of egg yolk proteins ( $\mathrm{Lv}, \mathrm{Pv}$ and $\left.\beta^{\prime}-\mathrm{c}\right)$, which are stored in eggs. The initial degradation during vitellogenesis is termed the first proteolysis, and later degradations during final maturation and embryogenesis are called the second and third proteolysis, respectively [21]. In addition to the first proteolysis described earlier, second proteolysis was first reported in mummichogs [69, 70], where egg yolk proteins were further degraded during the final maturation of the oocytes. This phenomenon is observed in fish living in seawater or brackish water whose oocytes absorb large amounts of water during the final stages of maturation [71, 72]. However, this second proteolysis is not observed in salmonids that lay their eggs in fresh water [43]. Matsubara and Sawano [73] described three types of egg yolk proteins $\left(\mathrm{Lv}, \mathrm{Pv}\right.$ and $\left.\beta^{\prime}-\mathrm{c}\right)$ in the barfin flounder that underwent first proteolysis and further degraded during the final maturation (second proteolysis), where the majority of $\mathrm{Pv}$ and $\beta^{\prime}$-c egg yolk proteins degraded into free amino acids (FAA). In addition, they determined that two types of Vtgs exist in the barfin flounder, and that the dual Lv variants correspondingly derived from each of these Vtgs were degraded differently during oocyte maturation. The two forms of Lv were found to be involved in controlling the buoyancy of eggs in the course of water absorption, with a differential contribution of FAA to the osmolyte pool, as well as being involved in the distribution of nutrients during early development [63]. In contrast, little has been reported about the third proteolysis of egg yolk proteins accompanying embryogenesis. In our study using salmonids, in which no second proteolysis was observed, we revealed that three types of egg yolk proteins ( $\mathrm{Lv}, \mathrm{Pv}$ and $\beta^{\prime}$-c) were subjected to separate degradations after fertilization, and that the degradation of $\mathrm{LvH}$ to smaller products and dephosphorylation of $\mathrm{Pv}$ occurred after the eyed embryo stage, while $\beta^{\prime}$-c remained intact throughout embryo development [43].

\section{Multiplicity of fish vitellogenins}

Recently, several Vtg gene transcripts were discovered in the African clawed frog (VtgA1, A2, B1, B2) [74, 75] and chicken (Vtg I, II, III) [76, 77], along with fish species such as mummichog [78, 79], barfin flounder [64], haddock Melanogrammus aeglefinus, a species of cod [80], tilapia Oreochromis aureus [81] and sheepshead minnow Cyprinodon variegatus, an estuarine-species of pupfish [82]. Among fishes, a gene encoding a special form of Vtg lacking the Pv region (phosvitinless Vtg, Pv-less Vtg) was first discovered in zebrafish Danio rerio [83]. In addition, genomic analysis of rainbow trout [84] revealed the presence of 20 active genes for Vtg as well as ten pseudogenes. The Vtg genes in rainbow trout had $\leq 3 \%$ sequence heterogeneity, and they likely encode nearly identical proteins. This gene redundancy probably occurs so that large amounts of Vtg can be synthesized by this species, which spawns comparatively large eggs.

In 2002, we successfully purified three different types of Vtgs from the blood plasma of white perch for the first time [58] and proposed a temporary classification for the three Vtg forms. Fish Vtgs can be divided into two main types, complete and incomplete [66] (Fig. 2). The complete Vtg has a deduced primary amino acid sequence composed of the five egg yolk protein regions described earlier $(\mathrm{LvH}$, $\mathrm{Pv}, \mathrm{LvL}, \beta^{\prime}$-c, C-terminal coding domain). As a result of the homology analysis, the complete $\mathrm{Vtg}$ was further divided into two subgroups, type $\mathrm{A}(\mathrm{Vtg} \mathrm{A})$ and type $\mathrm{B}(\mathrm{VtgB})$. The second major group, the incomplete $\mathrm{Vtg}$, mainly consists of $\mathrm{LvH}$ and $\mathrm{LvL}$, the main components of lipoprotein in fish eggs, and it has very low homology with the complete forms of Vtg. Pv-less Vtg in zebrafish (mentioned above) is considered to be an incomplete Vtg. Using the same classification system as the complete $\mathrm{Vtg}$, we named this incomplete Vtg as 'Vtg type C' $(\mathrm{VtgC})$. Because VtgA and $\mathrm{VtgB}$ have highly homologous primary structures and share similar characteristics such as molecular weight, the purification of individual proteins is difficult. In contrast, because $\mathrm{VtgC}$ has a lower molecular weight than the other two types, it is relatively easy to purify. To date, the complete $\mathrm{Vtg}(\mathrm{V} \operatorname{tg} \mathrm{A}$ and/or $\mathrm{VtgB})$ and incomplete $\mathrm{Vtg}(\mathrm{V} \operatorname{tg} \mathrm{C})$ have been successfully isolated and purified as two different proteins with distinct molecular weights and antigenicity in various fish species, including tilapia $(O$. aureus [85] and $O$. mossambicus [86]), medaka [87], Japanese goby Acanthogobius flavimanus [88] and Sakhalin taimen [89]. In addition, three distinct types of Vtg have been purified or detected in mosquitofish Gambusia affinis [90], red seabream Pagrus major [91] and grey mullet [92]. Two or three types of Vtgs have been detected as proteins with distinct antigenicity in various existing fish species [66]. Table 1 shows a summary of multiple Vtg genes and proteins reported in the literature [22].

The structure and function of fish Vtgs has diversified during the evolution. At present, fish Vtg genes are considered to have diversified through whole genome duplication (WGD) events, and also via lineage specific tandem gene duplication (TGD), followed by neofunctionalization. Recently, Finn and Kristoffersen [93] conducted detailed analyses of deduced amino acid sequences of Vtg gene transcripts from birds, amphibians and fish, and proposed a classification method based on the molecular evolution of Vtgs. According to their nomenclature, the 
Table 1 Multiple vitellogenin (Vtg) cDNA and protein in various teleosts

\begin{tabular}{|c|c|c|c|c|c|c|}
\hline \multirow[t]{2}{*}{ Species } & \multicolumn{3}{|l|}{ cDNA } & \multicolumn{3}{|l|}{ Protein } \\
\hline & $\mathrm{Vtg} \mathrm{A}(\mathrm{V} \operatorname{tg} \mathrm{Aa})^{*}$ & $\mathrm{Vtg} B(\mathrm{Vtg} A b) *$ & VtgC (Pv-less) & $\mathrm{Vtg} \mathrm{A}$ & VtgB & VtgC (Pv-less) \\
\hline Barfin flounder & 0 & 0 & & $500-520 \mathrm{kDa}$ & $530-550 \mathrm{kDa}$ & \\
\hline Red seabream & O & O & O & $610 \mathrm{kDa}$ & $610 \mathrm{kDa}$ & $340 \mathrm{kDa}$ \\
\hline Japanese common goby & O & & O & $530 \mathrm{kDa}$ & & $320 \mathrm{kDa}$ \\
\hline Mosquitofish & 0 & O & 0 & $600 \mathrm{kDa}$ & $600 \mathrm{kDa}$ & $400 \mathrm{kDa}$ \\
\hline Mummichog & ○ & ○ & 0 & & & \\
\hline Walleye pollock & O & O & & & & \\
\hline Medaka & 0 & 0 & O & $570 \mathrm{kDa}$ & & $460 \mathrm{kDa}$ \\
\hline White perch & 0 & 0 & O & $532 \mathrm{kDa}$ & $532 \mathrm{kDa}$ & $426 \mathrm{kDa}$ \\
\hline Grey mullet & $\begin{array}{l}\mathrm{O} \\
\mathrm{Vtg} *\end{array}$ & O & O & $570 \mathrm{kDa}$ & $580 \mathrm{kDa}$ & $335 \mathrm{KDa}$ \\
\hline Zebrafish & $\mathrm{O}(\mathrm{Vtg} \mathrm{Ao})$ & & O & VtgAs* & & \\
\hline Pacific herring & $\mathrm{O}(\mathrm{Vtg} A c)$ & & O & $540 \mathrm{kDa}$ & & $380 \mathrm{kDa}$ \\
\hline White spotted charr & O (VtgAs) & & 0 & & & \\
\hline
\end{tabular}

Vtgs formerly named VtgA and VtgB become VtgAa and $\mathrm{Vtg} \mathrm{Ab}$ paralogs, respectively. This nomenclature suggests that a chordate $\mathrm{Vtg}(\mathrm{V} \operatorname{tg} \mathrm{ABCD})$, considered to be the ancestor of vertebrate $\mathrm{Vtg}$, appeared during the first round of whole genome duplication (1R-WGD). For example, silver lamprey Ichthyomyzon unicuspis Vtg is classified as $\mathrm{VtgABCD}$. In the subsequent $2 \mathrm{R}-\mathrm{WGD}$, Vtgs were differentiated into $\mathrm{Vtg} \mathrm{AB}$ (chondrostean vitellogenin; found in chondrostean fish, amphibians and birds) and VtgCD. Later, during the 3R-WGD, $\operatorname{Vtg} A B$ allegedly differentiated to yield $\mathrm{Vtg} A$ (found in all teleosts) and $\mathrm{VtgB}$, and $\mathrm{VtgCD}$ was further divided into $\mathrm{VtgC}$ (fish $\mathrm{VtgC}$ or Pvless $\mathrm{Vtg}$ ) and $\mathrm{Vtg}$. The presence of genes encoding $\mathrm{Vtg} B$ and $\mathrm{VtgD}$ still remains unconfirmed among extant teleosts, suggesting that these genes may have been deleted after the 3R-WGD. VtgA supposedly experienced further lineage-specific gene duplication within teleosts, resulting in various paralogous and orthologous Vtg subtypes (e.g. VtgAa and $\mathrm{VtgAb}$ ). More specifically, fish belonging to Paracanthopterygii and Acanthopterygii, considered to be more evolved groups of fish, are supposed to possess all three Vtg orthologues (VtgAa, VtgAb and VtgC). In contrast, paralogous Vtg variants found in some other fish cannot be categorised as VtgAa, $\operatorname{VtgAb}$ or $\mathrm{VtgC}$. For example, the Salmonidae family in Protacanthoperygii differentiated relatively early in phylogeny and contains two types of Vtgs, one being a complete form of VtgA (salmonid-type A-type $\mathrm{Vtg}$ : VtgAs) that is not differentiated as $\mathrm{Vtg} A a$ or $\mathrm{Vtg} A b$, and the other, $\mathrm{Vtg} C$. With regard to the complete forms of Vtgs, VtgAo1 and VtgAo2 are present in Ostariophysi as Ostariophysian-type A-type Vtg, and VtgAe1, VtgAe2 and VtgAe3 are present in Elopomorpha as Elopomoruph-type A-type Vtgs. In both cases, VtgC
Fig. 3 Left Phylogenetic distribution of vitellogenin (Vtg) polypeptide sequences from selected egg-laying animals. Nomenclature of Vtg sequences follows a classification scheme proposed by Finn and Kristoffersen [93]. The analysis was performed using the neighbour-joining algorithm, and sequences were rooted using invertebrate Vtg sequences as an outgroup. Numbers besides nodes indicate the percent of bootstrap values for each branch of the tree in the 1000 bootstrap trials. Right Models representing the linearized domain structures of selected types of Vtgs

orthologues exist in addition to these paralogous VtgAs [24]. Figure 3 shows a molecular phylogenetic tree of amino acid sequences deduced from Vtg gene transcripts constructed by Finn and Kristoffersen [93], with some additional insights obtained through our research $[60,94$ 96]. It should be noted that more recent analyses of Vtg gene synteny have raised new questions concerning the relative importance of WGD versus TGD in the evolution of fish Vtgs and the timing of these duplications [97, 98], and indicate that the A-type and C-type Vtgs have a much longer evolutionary history (BP $\sim 425$ million) than previously thought. Nonetheless, the Vtg nomenclature proposed by Finn and Kristoffersen [93] remains applicable and useful for keeping track of Vtg gene orthology. The naming scheme for Vtgs should become more precise in the future as genetic and protein analyses become more advanced.

\section{Detection and measurement of fish vitellogenin}

Because fish Vtg is a protein containing approximately $1 \%$ phosphorous, $\mathrm{Vtg}$ in blood serum can be detected by staining with phosphorus dye after electrophoresis. In addition, Vtg can be indirectly quantified by measuring 


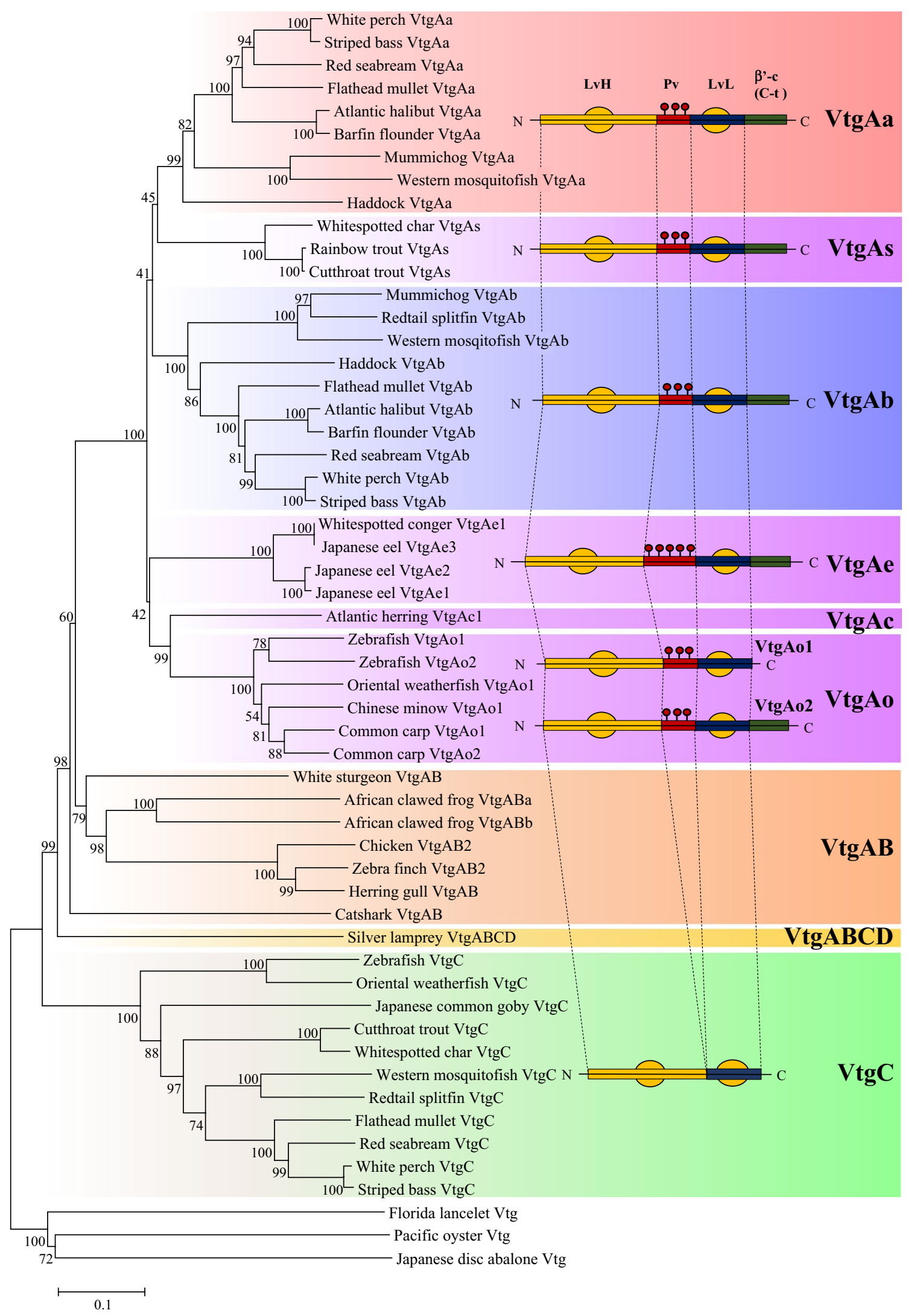


alkaline-labile phosphorus in blood serum. Furthermore, because of its high molecular weight, it can simply be detected by observing high-molecular-weight peaks that appear during gel-filtration chromatography [54]. However, qualitative and quantitative analyses based on immunological approaches using antibodies are generally superior. Because Vtgs are specifically found in females and induced by estrogen, and function as precursors of egg yolk proteins, three materials have been used as immunogens in the preparation of antibodies: (1) vitellogenic female blood serum, (2) blood serum of estrogen-treated fish, and (3) extracts of egg obtained during vitellogenesis. Female-specific antisera are prepared by subjecting antisera from animals (e.g. rabbits) immunized with these antigens to absorption procedures with male fish blood serum. Antisera prepared in this manner react strongly with Vtgs in female blood serum without reacting with male serum. Purified Vtg or egg yolk proteins ( $\mathrm{Lv}, \beta^{\prime}$-c) can also be used as immunogens. $\mathrm{Pv}$ reportedly has no antigenicity under normal circumstances; however, antibodies can be obtained by immunizing with dephosphorylated $\mathrm{Pv}$ [41]. The preparation of universal antibodies that react regardless of species is now under development using a well-conserved region of the Vtg molecule as a peptide antigen [22]. Here, we present a brief summary of Vtg immunoassay.

\section{Ouchterlony double immunodiffusion (agar gel immunodiffusion, passive double immunodiffusion)}

This is the simplest detection method. Samples such as blood serum and antibodies are placed in different holes (wells) on an agar gel plate and left from several hours to overnight to develop. Afterwards, a precipitation line generated by antibody-antigen complexes (precipitation reaction) appears. This method is semiquantitative with a detection sensitivity of approximately $10 \mu \mathrm{g} / \mathrm{ml}$. It requires relatively large amounts of antibodies compared with other methods introduced below and is low in Vtg detection sensitivity. However, it has advantages in its simplicity both in manipulation and required equipment [8].

\section{Mancini method (single radial immunodiffusion)}

This quantitative method has a similar sensitivity to the Ouchterlony double immunodiffusion. Agar gel plates containing antibodies are prepared in advance, and Vtg concentrations are measured by calculating the area of the precipitation ring that forms around the sample well. Because Vtg levels in the blood at the peak of vitellogenesis are quite high (approximately $40 \mathrm{mg} / \mathrm{ml}$ ) in Salmonidae, this method of detection and quantification is sufficient for these species under normal conditions $[8,68]$.

\section{Sensitive high-throughput immunoassays}

These are quantitative assays with high sensitivity: radio immunoassay (RIA), enzyme immunoassay (EIA), fluorescent immunoassay (FIA) and chemiluminescent immunoassay (CLIA). These methods share a common detection principle, but use different labeling methods. Using tracers (radioactive material, enzymes, fluorescent material and chemiluminescent material), these methods exhibit $>10,000$-fold higher sensitivity as compared to agar plate precipitation methods and can detect concentrations on the order of several tens of $\mathrm{pg} / \mathrm{ml}$. We introduce a CLIA method for the measurement of Vtg in Salmonidae, a sandwich method using no radiolabeled materials [22, 99]. Antibodies (anti- $\beta^{\prime}$-c antibodies) against Vtg were absorbed in a microtiter plate with 96 wells. Following this, known concentrations of Vtgs were added to the plate as standards, and samples were also added. Then, antibodies (antiLv antibodies) labeled with chemiluminescent acridinium were added to sandwich the Vtgs. Later, by measuring the luminescence of the labeled antibodies bound to the Vtgs, Vtg concentrations were calculated on the basis of a calibration curve $(60 \mathrm{pg} / \mathrm{ml}-500 \mathrm{ng} / \mathrm{ml})$ prepared in advance.

\section{Simple detection by immunochromatography}

In collaboration with a private company, we established a quick salmonid Vtg detection method by developing an immunochromatography-based method generally used in pregnancy tests and influenza tests. Immunochromatography results can be obtained within 2-15 min, with a detection sensitivity of $30 \mathrm{ng} / \mathrm{ml}$. Because this method offers a quick and more sensitive option than other conventional methods, it is useful for primary screening of proteins distributing in as wide a range of concentrations as Vtgs [22].

\section{Choriogenesis and choriogenin}

The egg membrane of teleosts (vitelline envelope, zona radiata or zona pellucida) consists of an extremely thin, high-density outer layer and a thick, low-density inner layer making up most of the structure. Some fish species have outer layers that are further divided into two parts. The timing of the formation of egg envelope components (choriogenesis) differs by layer. In general, outer layer formation starts around the perinucleolar oocyte stage, followed by the formation of the inner layer during the previtellogenic oocyte stage. Up until the mid-1980s, it was believed that proteins constituting the egg envelope were synthesized exclusively within the oocytes. However, a study of medaka [29] reported that a vitelline coat protein precursor synthesized in the liver after induction by estradiol- $17 \beta$ was 
secreted into the blood and deposited on the inner layer of the egg envelope. This liver-derived precursor of egg envelope protein was named Chg in mummichog and medaka [30]. To date, Chg has been isolated and purified in several fish species including medaka [100, 101], Sakhalin taimen [102], masu salmon Oncorhynchus masou [103], Atlantic cod [104] and red lip mullet Chelon haematocheilus [105], and the presence of two different Chgs with distinct molecular weights and antigenicities, namely Chg high molecular weight (Chg H) and Chg low molecular weight (Chg L), has been confirmed in these species (see Fig. 1).

Three Chg cDNAs that encode Chg H, Chg L and Chg $\mathrm{H}$ minor (Chg $\mathrm{Hm}$ ) were cloned from the medaka liver, and their high homology to zona pellucida glycoprotein (ZP: $\mathrm{ZPB}$ and $\mathrm{ZPC}$ ), which is synthesized in the mammalian ovary, was reported as well [106, 107]. In addition, three genes encoding egg envelope proteins, zpla, zplb and $z p 3$, were cloned from gilthead seabream Sparus aurata, and were reported to be highly expressed in the liver [108]. In addition to such liver-derived egg envelope-related genes, the presence of egg envelope-related genes exclusively expressed in the ovary was also found. In carp $[109,110]$ and zebrafish [111], the expression of ZP2 and ZP3 mRNA was only observed in the ovary, and based on deduced amino acid sequences, ZP2 and ZP3 reportedly have high homology to mammalian ZPB and ZPC, respectively. However, none of the liver-derived egg envelope-related genes mentioned above have been found in Cyprinidae. Based on these results, it has been concluded that the site(s) of egg envelope protein synthesis depends on the fish species, and that the mechanism of teleost choriogenesis can be divided into two major groups: 'liver type' (Chg type) in Oryziatidae and Salmonidae, in which egg envelope production is solely based on Chg, and 'ovary type' (ZP type) in Cyprinidae, in which the egg envelope is made from ZP proteins only. Recently, however, this classification was disproved by some new reports. According to these studies, $z p$ was obtained by cloning from the ovary of medaka [112] as well as from the liver. In addition, in masu salmon, three chg cDNAs encoding $\mathrm{Chg} \mathrm{H} \alpha, \beta$ and $\mathrm{Chg} \mathrm{L}$ were cloned from the liver of mature females [113], and two $z p$ cDNAs were cloned from the ovary (ZPB [114] and ZPC [Fujita and Hara, unpubl. data]), revealing the presence of five egg envelope protein-related genes in total. Therefore, it appears that both Chg and ZP are generally involved in choriogenesis in fish that was formerly categorised as 'liver type', and both proteins can be expected to contribute to the complex structure of the egg envelope of these species. However, among fish categorized as having 'liver type' egg envelope precursors, the presence of ZP has been reported only in the two aforementioned species along with gilthead seabream, and the role of ZP in choriogenesis remains unclear. This suggests the possibility that, in general, both
Chg and ZP are involved in choriogenesis in fish and that the variations in the mechanism of egg envelope formation arise from structural differences between Chg and ZP as well as the amounts of each protein that are synthesized.

Because the formation of the egg envelope starts before the accumulation of egg yolk, Chg synthesis may occur at an earlier stage of sexual maturation than Vtg synthesis. Such differences in the timing of synthesis may involve different sensitivities of the transcriptional response of each gene to estrogen stimulation. To date, we have purified two types of Chg (Chg H and Chg L) from salmonid species using methods similar to those used to purify medaka Chgs, and we have established a Mancini assay and EIA using antibodies raised against these proteins [115]. In masu salmon treated with estrogen, blood concentrations of two types of Chg exceeded that of Vtg when a low concentration of estrogen was used; the Vtg level surpassed the Chg levels when the estrogen concentration was increased. A similar phenomenon was also observed in female fish during sexual maturation at the transition between previtellogenic and vitellogenic stages. As observed in such cases, when induced by low concentrations of estrogen, blood levels of Chg exceeded those of Vtg, which suggests that Chg is a suitable marker of the effect of estrogen-like substances present at low concentrations [116]. Although the absence of Chg in the fish with 'ovary-type' egg envelope precursors needs to be taken into consideration, Chg is expected to be a useful biomarker for assessing the effect of estrogen-like substances in aquatic environments when examining fish with 'liver type' egg envelope precursors, perhaps in combination with Vtg measurements.

\section{Applications of vitellogenin as biomarkers for detection of estrogenic activity}

Various chemicals associated with human activities are present in aquatic environments. Such chemicals include compounds that demonstrate estrogen-like activity, called estrogenic endocrine-disrupting chemicals (EEDCs). The effects of EEDCs on aquatic organisms have been of growing concern, particularly in Europe and North America. More recently, evidence of the widespread presence of EEDCs has been reported in Japan as well, and similar situations are presumed to be occurring in neighbouring Asian countries [22].

At present, the most reliable methods available for examining EEDC activity in water include the detection of Vtg induced in the blood of male or juvenile fish. As described previously, Vtg is a precursor of egg yolk proteins; its synthesis is controlled by estradiol-17 $\beta$ in the liver of female fish during maturation, and it is taken into oocytes after being transferred to the ovary via the blood 
(see Fig. 1). Vtg can also be induced in the blood of male or juvenile fish exposed to exogenous estrogen, and the presence of $\mathrm{Vtg}$ in the blood of males or juveniles has been widely accepted as a biomarker of their exposure to EEDCs $[21,22,31,32]$.

Various immunoassays for Vtg have been established in many fish species for detecting their exposure to EEDCs. Most of these methods have been developed under the premise of the 'single Vtg model'. More recently, however, the measurement of Vtg subtypes has been attempted in fish species in which Vtg polymorphisms were identified. In general, a complete form of Vtg is the major subtype and the incomplete $\mathrm{Vtg}(\mathrm{VtgC})$ is often a minor subtype [22]. This is particularly true for Salmonidae. In addition, in fish species where the complete form of $\mathrm{Vtg}$ has been further classified into $\mathrm{VtgAa}$ and $\mathrm{VtgAb}$, the ratio of subtypes present in the blood depends on each species [117, 118]. Because of the large molecular weight differences, the ratio of complete to incomplete forms of Vtg can be readily determined by electrophoresis and similar methods. In contrast, multiple subtypes of Vtg often have identical or extremely similar molecular weights, and, as noted, they are difficult to separate or individually identify at the protein level. In such cases, major Vtg subtypes can be identified using quantitative real-time PCR, to measure their subtype-specific mRNA. The obtained Vtg gene expression profiles represent a valid index for the detection and assessment of EEDC activity in addition to Vtg protein expression. In general, after exposure to estrogen, Vtg protein in the blood can be detected for a longer period of time than Vtg mRNA in the liver, suggesting that each measurement reflects a distinct exposure history, with the elevation of Vtg mRNA levels in the liver being a temporary phenomenon reflecting more recent exposure than protein detection in the blood. Ideally, the detection of both products will enable chronological assessments in terms of EEDC exposure history [66].

\section{Evaluation on effects of estrogenic endocrine disrupting chemicals}

The detection of EEDC activity in the field using fish Vtg as an index was first reported from the UK in 1995 [31]. In that study, male rainbow trout were placed in a cage downstream from a drainage channel. Increased Vtg levels in their blood were documented and the values were compared with those of trout from a control site. Based on the results, the authors suggested estrogenic activity in wastewater drainage and identified nonylphenol as the causative agent. Since then, similar studies have been conducted in Salmonidae and Cyprinidae. In vitro exposures have also been performed in Salmonidae and small freshwater fish, and various insights have accumulated regarding the association between Vtg induction and abnormal reproductive functions. Because small freshwater fish such as medaka and zebrafish are easy to breed and have a relatively short lifespan and generation interval, many laboratory exposure studies have used such fish species [22].

Rainbow trout and masu salmon are small Salmonidae that can be cultured in ponds where they can complete their entire life cycle. We established CLIA for two types of Vtgs in pond-grown masu salmon; namely, a complete form of $\mathrm{Vtg}(\mathrm{Vtg} A s)$ and an incomplete form of $\mathrm{Vtg}(\mathrm{VtgC})$, and observed the changes in blood levels during sexual maturation. Concentrations of complete and incomplete forms of $\mathrm{Vtgs}$ in the female blood during vitellogenesis were around 100 and $50 \mathrm{ng} / \mathrm{ml}$, respectively, demonstrating approximately twice the amount of the complete form compared to the incomplete form. In contrast, at the peak of vitellogenesis, blood levels of complete and incomplete forms of Vtg were approximately 20 and $\leq 0.5 \mathrm{mg} / \mathrm{ml}$, respectively, yielding a relatively large ratio of 40:1. Because both types of $\mathrm{Vtg}$ are controlled by estradiol-17 $\beta$, the fluctuation of this ratio is thought to be due to hormone sensitivity differences of each gene subtype [Nishikawa and Hara, unpubl. data]. At present, the mechanism that controls the Vtg synthesis ratios is unknown; however, a recent study suggested that the synthesis ratio of two types of Chgs, induced in a similar manner as Vtgs, was also dependent on the amount of estrogen administered [115]. These studies suggest that to conduct an accurate assessment of contamination, we need to consider the possibility that an incomplete form of Vtg (a minor component of female blood during vitellogenesis) is synthesized as a relatively major component in the presence of low concentrations of estrogen. In fact, although almost no complete forms of Vtgs were detected in the blood of pond-grown male masu salmon, trace amounts of incomplete Vtg (VtgC) [Fujita and Hara, unpubl. data] and Chg have been detected throughout the year [119].

Lately, the number of reports on assessment of the effects of EEDCs in marine fish has been growing. Estrogen activity has been mainly detected in Heterosomata and Gobiidae particularly in the coastal areas of Japan, Europe and North America [66]. To date, our research group has been conducting a study of EEDC activity along the coasts of Japan, Korea and China, targeting Mugilidae. In this study, we targeted two types of Mugilidae to expand the area of investigation: grey mullet that is widely distributed in the south, and red lip mullet in the north. For the grey mullet, various analyses have been conducted, including a qualitative analysis of multiple Vtgs and their product egg yolk proteins, gene cloning and characterization of multiple Vtg subtypes, and confirmation of estrogen response. Additionally, a Vtg measurement system specific for the various 
Vtg subtypes has been developed, establishing an assessment system that fully considers the 'multiple Vtg model' mentioned above [118]. Furthermore, in red lip mullet, we established identification and measurement systems for major Vtg subtypes and confirmed estrogen responsiveness. Moreover, we developed systems for qualitative analysis, identification, and measurement of Chg and attempted a preliminary investigation using a model river [105]. Until now, the investigation targeting both species of Mugilidae detected extremely high estrogen activity in urban coastal waters, and histopathological observations revealed some fish to have abnormal gonads, including ovotestes. However, the connection between blood Vtg levels and these reproductive abnormalities has not yet been confirmed [120].

Adding to in vivo experiments where small fish were exposed to estrogen and EEDCs, studies of free-ranging fishes in freshwater and marine waters contaminated with estrogenic compounds have generated a relatively large amount of useful information. However, our insight into the activity of EEDCs in the open ocean is still limited. Pink salmon Oncorhynchus gorbuscha and chum salmon, members of Salmonidae that undertake a feeding migration over long distances in the open ocean, are appropriate target species for investigation in northern oceanic areas. We collected pink salmon and chum salmon off the coast in the North Pacific and measured Vtg and Chg levels in the male blood. Although some Vtg and Chg were detected in male fish collected from the open sea, levels were within the normal range (baseline) for Salmonidae, suggesting that the open seawater is relatively clean and free from significant contamination with estrogenic compounds. In addition, when we measured blood Vtg levels of male salmon returning to major rivers in Hokkaido, the levels were even lower than those observed in males collected in the open ocean. Although the reason for this phenomenon is unclear, no EEDC activity has been detected to date in major rivers in Hokkaido, indicating that there is no effect on homing migration and early development of Salmonidae in the area [Takahashi and Hara, unpubl. data].

\section{Interpretation of vitellogenin induction}

When using Vtg detected in male or immature fish blood as a biomarker of EEDC activity, care must be taken to ensure appropriate interpretation. For instance, in in vivo exposure experiments or caging experiments conducted in the field, the level of Vtg in each individual prior to the start of the experiment can be used as a baseline control, enabling unambiguous detection of the presence or absence of EEDC activity within the targeted area. However, no clear baseline Vtg level can be set for experiments with wild fish. Therefore, the presence of Vtg in the blood of male or immature fish does not necessarily indicate exposure to EEDCs, unless the presence of Vtg is correlated with other observations indicative of such exposure, such as gonadal or other physical reproductive abnormalities. Since the establishment of Vtg measurement systems with high sensitivity, low levels of Vtg have actually been detected in reproductively normal male individuals of several fish species [22]. Possible causes of the appearance of male fish with low levels of Vtg are: (1) low-level endogenous estrogen, (2) feed-derived estrogen, and (3) estrogen derived from excretion or secretions from female fish cohabiting in proximal areas during the spawning season. Furthermore, blood Vtg levels in normal male fish may vary depending on the species, season and maturity of the fish. Therefore, in every EEDC activity assessment in the aquatic environment, the normal range of the Vtg level (baseline) of the target male fish needs to be known beforehand. We have been investigating these baselines in several index fish species [22, 66]. For Salmonidae, using pond-grown masu salmon or Sakhalin taimen bred for many generations in captivity and confirmed to have normal reproductive functions, by measuring the Vtg levels through a whole year, we determined the species baseline Vtg levels.

Vtg levels in the blood of males that exceed the baseline suggest that the targeted individual is or has been exposed to EEDCs in the relatively recent past. However, even when temporary induction of Vtg exceeding the baseline level is observed in a male individual, its effects on reproduction (e.g. abnormalities in gonad morphology, reproductive behaviour, fertilization, development and sexual differentiation) largely depend on individual differences, including age. In general, the EEDC exposure level that is required for the induction of $\mathrm{Vtg}$ is lower than that associated with reproductive abnormalities. In contrast, $\mathrm{Vtg}$ induction occurs at or above the EEDC exposure level that triggers reproductive abnormalities in immature fish [22]. Therefore, when an abnormal Vtg level is detected in a wild mature male fish, it is highly likely that reproductive abnormality has already been progressing among other immature fish from the same area, even if no reproductive abnormality has been detected in the tested mature male individuals. As shown here, the results of field research not only demonstrate the current or relatively recent history of exposure of targeted individuals to EEDCs, but also predict the development of reproductive disorders in immature fish, including juveniles or fry, and can be considered as an early warning.

The discovery of multiple (polymorphous) Vtgs in fish may lead to new interpretations of the assessment results of EEDC contamination based on Vtg measurements. Our recent research on the physiological functions of each type of Vtg during oocyte maturation and embryogenesis 
following fertilization suggested that egg quality is directly dependent on the relative abundance (accumulation ratio) of each Vtg within the ovulated eggs [117, 118]. Assuming that this hypothesis is correct, when EEDCs disrupt the ratios of different forms of Vtgs found in the blood or accumulated in the egg, this suggests a potential direct impact on fertilization or survival rates. Until recently, only male or immature fish have been targeted in Vtg-based EEDC contamination studies. In the future, the ratios of multiple Vtgs in the blood of mature female fish and those accumulated in eggs are expected to function as novel biomarkers of endocrine disruption caused by EEDCs.

\section{Future concerns}

Having summarized information on Vtg and Chg as major proteins involved in oogenesis, we will now discuss a few ongoing studies. Until recently, fish Vtg protein has mainly been studied as an index for gender identification in farmed fish or for assessing estrogenic activity in fish in aquatic environments. Future studies should focus on analysis of Vtg polymorphisms from a physiological standpoint, following the entire process of vitellogenesis within a species, beginning with Vtg synthesis in the liver and ending with the migration of secreted proteins from the blood into the egg yolk. To generalise the concept of a 'multiple Vtg model', it is also essential to collect data regarding polymorphous Vtg from a wide variety of fish species. We have been conducting a detailed analysis of two types of Vtg in Salmonidae for the first time, analyzing the primary structure of yolk protein domains and their characteristic motifs and revealing the expression profile of each form of $\mathrm{Vtg}$ during ovarian development [95].

Even less information is known about Vtg receptors. To date, only a limited number of studies have examined the relationships between receptor proteins and their Vtg ligands. Recently, based on an experiment using a yeast 2-hybrid system $(\mathrm{Y} 2 \mathrm{H})$, the affinity between $\mathrm{VtgAb}$ and the $\mathrm{Vtg}$ receptor (an orthologue of mammalian very-low-density lipoprotein (VLDL) receptor) was confirmed in tilapia, and the binding regions were revealed to be located in the $\mathrm{LvH}$ region of $\mathrm{VtgAb}$ and on a ligand-binding repeat of the Vtg receptor [121]. This finding is in agreement with our experimental results, which biochemically demonstrated the presence of a binding region on Lv that binds to the Lr8-type Vtg receptor [65]. Moreover, Mizuta et al. [122] prepared a specific antibody to a recombinant homologue of the Lr8-type Vtg receptor in cutthroat trout Oncorhynchus clarki and immunobiochemically proved that an approximately $100 \mathrm{kDa}$ receptor protein was the translation product of the gene encoding the Lr8-type Vtg receptor. Furthermore, immunohistochemical analysis using the same antibody demonstrated that the
Lr8-type Vtg receptor protein is mainly located at the periphery of oocyte membranes within the ovary, supporting the hypothesis that the Lr8-type receptor binds to Vtg at this same site to be taken up into oocytes. Additional insights on the fish Lr8-type Vtg receptor have been accumulating; however, when considering the 'multiple Vtg model', almost no information is available regarding the binding of different Vtg subtypes with the Lr8-type Vtg receptor. In an experiment with white perch, Reading et al. [123, 124] confirmed the possibility that $\mathrm{VtgAa}$ and $\mathrm{VtgAb}$ may bind to different receptors and indicated that in addition to the Lr8-type Vtg receptor, a novel lipoprotein receptor (low-density lipoprotein receptor-related protein 13, Lrp13) may be involved in Vtg binding. Many unidentified lipoprotein receptors exist in fish, and the affinity of these receptors for Vtg will likely be revealed in the future.

Many fish eggs contain not only Vtg-derived lipids (mainly phospholipids), but also neutral lipids (mainly triglyceride or wax esters) called 'oil globules'. Because some fish species accumulate oil globules in a similar quantity as yolk granules, they may play an important role in the development of embryos and juvenile fish. However, their mechanism of formation, including their origins, remains unknown for the most part. We hypothesised that oil globules originate from a group of serum proteins rich in neutral lipids (e.g. VLDL), and we have attempted to construct a novel model for oil globule accumulation. At present, there are two proposed models: (1) a pathway where an oil globule is formed with free fatty acids released from VLDL by lipase in the blood and subsequently taken into the ovum and (2) a pathway where VLDL enters directly via a receptor and the release of fatty acids and synthesis of oil globules occur within the ovum. Experiments are currently in progress. To date, our focus has been on lipase and fatty acid transport molecules involved in the first pathway described above, and we have been investigating the location of expression of each molecule within follicles and the expression dynamics during oogenesis. For instance, when we analysed the dynamics and location of the expression of lipase in the ovary of cutthroat trout, we found that the protein was strongly expressed in the granulosa cell layer, and its expression increased in the oil droplet stage in which oil globule formation starts, followed by a decrease with the advance of vitellogenesis [125].

Fish oogenesis, particularly the formation of the yolk globules, egg envelope and oil globules, involves very precise regulatory mechanisms and is of direct relevance to final egg quality and seed integrity. This process, by which a primary oocyte grows by several orders of magnitude while accumulating or synthesizing everything necessary to eventually be fertilized and support complete development of a new life, is amongst the most intriguing of biological phenomena. Advances in our comprehensive understanding 
of this event will undoubtedly contribute to the development of applied technologies to improve the egg quality and seed integrity in farmed fishes and to protect reproductive processes in wild fish.

Acknowledgments This study started when one of the authors, Akihiko Hara, was under the supervision of late professor emeritus Hidematsu Hirai, along with several other professors in the Department of Biochemistry, Hokkaido University School of Medicine. We received generous cooperation from Professor Craig V. Sullivan at North Carolina State University, who has been a long-term collaborator. We would like to express our gratitude to Drs. Takahiro Matsubara, Kiyoshi Soyano, Takashi Todo, Munetaka Shimizu, Haruhisa Fukada, Makiko Kitamura, Nobuyuki Okubo, Haruna Amano, Hong Lei, Yuka Morita, Yong-Woon Ryu, Hiroko Mizuta, Wu Meiqin, Osamu Nishimiya, Yuji Mushirobira and other graduate students, who made significant contributions to studies described in this article.

Open Access This article is distributed under the terms of the Creative Commons Attribution 4.0 International License (http://creativecommons.org/licenses/by/4.0/), which permits unrestricted use, distribution, and reproduction in any medium, provided you give appropriate credit to the original author(s) and the source, provide a link to the Creative Commons license, and indicate if changes were made.

\section{References}

1. Uhlenhuth P, Kodama T (1914) Studien über die Geschlechtsdifferenzierung. Kokka Igakkai Zashi 324-335:385-405 (in Japanese)

2. Sakuma K (1923) On the precipitin reaction of the reproductive cells and the sexual differences. Nippon Fujinka-Gakkai Zasshi 18:1101-1126 (in Japanese)

3. Deutsch HF, Goodloe MB (1945) An electrophoretic survey of various animal plasmas. J Biol Chem 161:1-20

4. Deutsch HF, McShan WH (1949) Biophysical studies of blood plasma proteins XII. Electrophoretic studies of the blood serum proteins of some lower animals. J Biol Chem 180:219-234

5. Moore DH (1945) Species differences in serum protein patterns. J Biol Chem 161:21-32

6. Saito K (1957) Biochemical studies on the fish blood-VIII. On the electrophoretic specificity of serum proteins. Nippon Suisan Gakkaishi 22:752-759 (in Japanese with English abstract)

7. Saito K (1957) Biochemical studies on the fish blood-IX. On the paper electrophoretic analysis of serum proteins. Nippon Suisan Gakkaishi 22:760-767 (in Japanese with English abstract)

8. Hara A (1987) Studies on female-specific serum proteins (vitellogenin) and egg yolk proteins in teleosts: immunochemical, physicochemical and structural studies. Mem Fac Fish Hokkaido Univ 34:1-59

9. Vanstone WE, Ho CW (1961) Plasma proteins of coho salmon, Oncorhynchus kisutch, as separated by zone electrophoresis. J Fish Res Bd Can 18:393-399

10. Krauel KK, Ridgway GJ (1963) Immunoelectrophoretic studies of red salmon (Oncorhynchus nerka) serum. Int Archs Allergy appl Immun 23:246-253

11. Utter FM, Ridgway GJ (1967) A serologically detected serum factor associated with maturity in English sole, Parophrys vetulus, and Pacific halibut, Hippoglossus stenolepis. Fish Bull Fish Wildl Serv US 66:47-58
12. Amirante GA (1972) Immunochemical studies on rainbow trout (Salmo gairdnerii Rich.) lipovitellin. Acta Embryol Exp Suppl:373-383

13. Aida K, Ngan PV, Hibiya T (1973) Physiological studies on gonadal maturation of fishes. I. Sexual difference in composition of plasma protein of ayu in relation to gonadal maturation. Nippon Suisan Gakkaishi 39:1091-1106

14. Emmersen BK, Petersen IM (1976) Natural occurrence, and experimental induction by estradiol-17- $\beta$, of a lipophosphoprotein (vitellogenin) in flounder (Platichthys flesus, L.). Comp Biochem Physiol 54B:443-446

15. Hara A (1976) Iron-binding activity of female-specific serum proteins of rainbow trout (Salmo gairdneri) and chum salmon (Oncorhynchus keta). Biochim Biophys Acta 427:549-557

16. Pan MJ, Bell WJ, Telfer WH (1969) Vitellogenic blood protein synthesis by insect fat body. Science 165:393-394

17. Wallace RA (1985) Vitellogenesis and oocyte growth in nonmammalian vertebrates. In: Browder LW (ed) Development Biology, vol 1. Plenum Press, New York, pp 127-177

18. Mommsen TP, Walsh PJ (1988) Vitellogenesis and oocyte assembly. In: Hoar WS, Randall DJ, Farrell AP (eds) Fish physiology, vol 11A. Academic Press, San Diego, New York, pp 347-406

19. Selman K, Wallace RA (1989) Cellular aspects of oocyte growth in teleost. Zool Sci 6:211-231

20. Specker JL, Sullivan CV (1994) Vitellogenesis in fishes: status and perspectives. In: Davey KG, Petter RE, Tobe SS (eds) Perspectives in comparative endocrinology. National Research Council, Ottawa, pp 304-315

21. Hiramatsu N, Matsubara T, Weber GM, Sullivan CV, Hara A (2002) Vitellogenesis in aquatic animals. Fish Sci 68(Suppl I):694-699

22. Hiramatsu N, Cheek AO, Sullivan CV, Matsubara T, Hara A (2005) Vitellogenesis and endrocrine disruption. In: Mommsen TP, Moon TW (eds) Biochemistry and molecular biology of fishes, vol 6. Elsevier Science, Amsterdam, pp 431-471

23. Patiño R, Sullivan CV (2002) Ovarian follicle growth, maturation, and ovulation in teleost fish. Fish Physiol Biochem 26:57-70

24. Reading BJ, Sullivan CV (2011) Vitellogenesis in fishes. In: Ferrell AP (ed) Encyclopedia of fish physiology: from genome to environment. The reproductive organs and processes. Elsevier, Maryland Heights, Missouri, pp 635-646

25. Plack PA, Pritchard DJ, Fraser NW (1971) Egg proteins in cod serum. Biochem J 121:847-856

26. Hara A, Takano K, Hirai H (1983) Immunochemical identification of female-specific serum protein, vitellogenin, in the medaka, Oryzias latipes (teleosts). Comp Biochem Physiol 74A:135-141

27. Hara A, Takemura A, Matsubara T, Takano K (1986) Immunochemical identification of female-specific serum proteins in a viviparous fish, the white-edged rockfish (Sebastes taczanowskii), during vitellogenesis and pregnancy, and after estrogen treatment. Bull Fac Fisheries Hokkaido Univ 37:101-110 (in Japanese with English abstract)

28. Matsubara T, Wada T, Hara A (1994) Purification and establishment of ELISA for vitellogenin of Japanese sardine (Sardinops melanostictus). Comp Biochem Physiol 109B:545-555

29. Hamazaki T, Iuchi I, Yamagami Y (1984) Chorion glycoproteinlike immunoreactivity in some tissues of adult female medaka. Zool Sci 1:148-150

30. Yamagami K (1996) Studies on the hatching enzyme (choriolysin) and its substrate, egg envelope, constructed of the precursors (choriogenins) in Oryzias latipes: a sequel to the information in 1991/1992. Zool Sci 13:331-340 
31. Sumpter JP, Jobling S (1995) Vitellogenesis as a biomarker for estrogenic contamination of the aquatic environment. Environ Health Perspect 103:173-178

32. Sumpter JP (1997) Environmental control of fish reproduction: a different perspective. Fish Physiol Biochem 17:25-31

33. Arcand-Hoy LD, Benson WH (1998) Fish reproduction: an ecologically relevant indicator of endocrine disruption. Environ Toxicol Chem 17:49-57

34. Giesy JP, Snyder EM (1998) Xenobiotic modulation of endocrine function in fish. In: Kendall RJ, Dickerson RL, Giesy JP, Suk WA (eds) Principles and processes for evaluating endocrine disruption in wildlife. SETAC Press, Florida, pp 155-237

35. Kime DE (1998) Endocrine disruption in fish. Kluwer Academic Publishers, Boston 416 pp

36. Pait AS, Nelson JO (2002) Endocrine disruption in fish: an assessment of recent research and results, NOAA Technical Memo. NOS NCCOS CCMA 149, Silver Spring, MD, NOAA, NOS, Center for Coastal Monitoring and Assessment

37. Arukwe A, Goksøyr A (2003) Eggshell and egg yolk proteins in fish: hepatic proteins for the next generation: oogenetic, population, and evolutionary implications of endocrine disruption. Comp Hepatol 2:1-21

38. Bergink EW, Wallace RW (1974) Precursor-product relationship between amphibian vitellogenin and yolk proteins, lipovitellin and phosvitin. J Biol Chem 249:2897-2903

39. Deeley RG, Mullinix KP, Wetekam W, Kronenberg HM, Meyers M, Eldridge JD, Goldberger RF (1975) Vitellogenin synthesis in the avian liver: vitellogenin is the precursor of the egg yolk phosphoproteins. J Biol Chem 250:9060-9066

40. Hara A, Hirai H (1978) Comparative studies on immunochemical properties of female-specific serum protein and egg yolk proteins in rainbow trout (Salmo gairdneri). Comp Biochem Physiol 59B:339-343

41. Hiramatsu N, Hara A (1996) Relationship between vitellogenin and its related egg yolk proteins in Sakhalin taimen (Hucho perryi). Comp Biochem Physiol 115A:243-251

42. Hiramatsu N, Hara A (1997) Specific proteolysis of vitellogenin to egg yolk proteins in white spotted-charr Salvelinus leucomaenis. Nippon Suisan Gakkaishi 63:701-708 (in Jananese with English abstract)

43. Hiramatsu N, Ichikawa N, Fukada H, Fujita T, Sullivan CV, Hara A (2002) Identification and characterization of proteases involved in specific proteolysis of vitellogenin and yolk proteins in salmonids. J Exp Zool 292:11-25

44. Hiramatsu N, Fukada H, Sullivan CV, Hara A (2001) Simple and sensitive detection of vitellogenin receptor(s) in Sakhalin taimen (Hucho perryi). Bull Fish Hokkaido Univ 52:5-9

45. Hara A (1978) Sexual differences in serum proteins of chum salmon and the purification of female-specific serum protein. Nippon Suisan Gakkaishi 44:689-693 (in Japanese with English abstract)

46. Campbell CM, Idler DR (1980) Characterization of an estradiol-induced protein from rainbow trout as vitellogenin by the cross reactivity to ovarian yolk fractions. Biol Reprod 22:605-617

47. Idler DR, Hwang SJ, Crim LW (1979) Quantification of vitellogenin in Atlantic salmon (Salmo salar) plasma by radioimmunoassay. J Fish Res Bd Can 36:574-578

48. Hori SH, Kodama T, Tanahashi K (1980) Induction of vitellogenin synthesis in goldfish by massive doses of androgens. Gen Comp Endocrinol 37:306-320

49. de Vlaming VL, Wiley HS, Delahuntry G, Wallace RA (1980) Goldfish (Carassius auratus) vitellogenin: Induction, isolation, properties and relationship to yolk proteins. Comp Biochem Physiol 67B:613-623
50. Hara A, Yamauchi K, Hirai H (1980) Studies on female-specific serum protein (vitellogenin) and egg yolk protein in Japanese eel (Anguilla japonica). Comp Biochem Physiol 65B:315-320

51. Nath P, Sundararaj BI (1981) Isolation and identification of female-specific serum lipophosphoprotein (vitellogenin) in the catfish, Heteropneustes fossilis. Gen Comp Endocrinol 43:184-190

52. Wallace RA, Selman K (1982) A new procedure for the isolation of intact vitellogenin from teleosts. In: Richter CJJ, Goos HJTh (eds) Proceedings of the international symposium on reproductive physiology of fish, Wageningen, The Netherlands, p 161

53. Gordon MR, Owen TG, Ternan TA, Hildebrand LD (1984) Measurement of a sex-specific protein in skin mucus of premature coho salmon (Oncorhynchus kisutch). Aquaculture 43:333-339

54. Hara A, Sullivan CV, Dickhoff WW (1993) Isolation and some characterization of vitellogenin and its related egg yolk proteins from coho salmon (Oncorhynchus kisutch). Zool Sci $10: 245-256$

55. Jared DW, Wallace RA (1968) Comparative chromatography of the yolk proteins of teleosts. Comp Biochem Physiol 24:437-443

56. Markert JP, Vanstone WE (1971) Egg proteins of coho salmon (Oncorhynchus kisutch). J Fish Res Bd Can 28:1853-1856

57. Matsubara T, Koya Y (1997) Course of proteolytic cleavage in three classes of yolk proteins during oocyte maturation in barfin flounder Verasper moseri, a marine teleost spawning pelagic eggs. J Exp Zool 272:34-45

58. Hiramatsu N, Matsubara T, Hara A, Donato DM, Hiramatsu K, Denslow ND, Sullivan CV (2002) Identification, purification and classification of multiple forms of vitellogenin from white perch (Morone americana). Fish Physiol Biochem 26:355-370

59. Amano H, Fujita T, Hiramatsu N, Shimizu M, Sawaguchi S, Matsubara T, Kagawa H, Nagae M, Sullivan CV, Hara A (2007) Egg yolk proteins in gray mullet (Mugil cephalus): purification and classification of multiple lipovitellins and other vitellogenin-derived yolk proteins and molecular cloning of the parent vitellogenin genes. J Exp Zool 307A:324-341

60. Yamane K, Yagai T, Nishimiya O, Sugawara R, Amano H, Fujita T, Hiramatsu N, Todo T, Matsubara T, Hara A (2013) Characterization of vitellogenin and its derived yolk proteins in cloudy catshark (Scyliorhinus torazame). Fish Physiol Biochem 39:373-390

61. Shimizu Y, Nakamura A, Kishimura H, Hara A, Watanabe K, Saeki H (2009) Major allergen and its IgE cross-reactivity among salmonid fish roe allergy. J Agric Food Chem 57:2314-2319

62. Yamamura JI, Adachi T, Aoki N, Nakajima H, Nakamura R, Matsuda T (1995) Precursor-product relationship between chicken vitellogenin and the yolk proteins: the $40 \mathrm{kDa}$ yolk plasma glycoprotein is derived from the C-terminal cysteinerich domain of vitellogenin II. Biochim Biophys Acta 1244:384-394

63. Matsubara T, Nagae M, Ohkubo N, Andoh T, Sawaguchi S, Hiramatsu N, Sullivan CV, Hara A (2003) Multiple vitellogenins and their unique roles in marine teleosts. Fish Physiol Biochem 28:295-299

64. Matsubara T, Ohkubo N, Andoh T, Sullivan CV, Hara A (1999) Two forms of vitellogenin, yielding two distinct lipovitellins, play different roles during oocyte maturation and early development of barfin flounder, Verasper moseri, a marine teleost spawning pelagic eggs. Dev Biol 213:18-32

65. Hiramatsu N, Hara A, Hiramatsu K, Fukada H, Weber GM, Denslow ND, Sullivan CV (2002) Vitellogenin-derived yolk 
proteins of white perch, Morone americana: purification, characterization and vitellogenin-receptor binding. Biol Reprod 67:655-667

66. Hiramatsu N, Matsubara T, Fujita T, Sullivan CV, Hara A (2006) Multiple piscine vitellogenins: biomarkers of fish exposure to estrogenic endocrine disruptors in aquatic environments. Mar Biol 149:35-47

67. Kanetoshi A, Katsura E, Fujimoto T, Kojima H, Hori Y, Fukada H, Takahara S, Hara A (2004) Study on the screening test of endocrine disrupting chemicals using carp (Cyprinus carpio) hepatocyte culture: vitellogenin induction test by estrogens. Rep Hokkaido Inst Pub Health 54:1-6 (in Japanese with English abstract)

68. Hiramatsu N, Shimizu M, Fukada H, Kitamura M, Ura K, Fuda H, Hara A (1997) Transition of serum vitellogenin cycle in Sakhalin taimen (Hucho perryi). Comp Biochem Physiol 118C:149-157

69. Wallace RA, Begovac PC (1985) Phosvitins in Fundulus oocytes and eggs: preliminary chromatographic and electrophoretic analyses together with biological considerations. J Biol Chem 260:11268-11274

70. Wallace RA, Selman K (1985) Major protein changes during vitellogenesis and maturation of Fundulus oocytes. Dev Biol 110:492-498

71. Greeley MS Jr, Calder DR, Wallace RA (1986) Changes in teleost yolk proteins during oocyte maturation: correlation of yolk proteolysis with oocyte hydration. Comp Biochem Physiol 84B:1-9

72. Matsubara T, Adachi S, Ijiri S, Yamauchi K (1995) Changes of lipovitellin during in vitro oocyte maturation in Japanese flounder, Paralichthys olivaceus. Fish Sci 61:478-481

73. Matsubara T, Sawano K (1995) Proteolytic cleavage of vitellogenin and yolk proteins during vitellogenin uptake and oocyte maturation in barfin flounder (Verasper moseri). J Exp Zool 272:34-45

74. Wahli W, Dawid IB, Wyler T, Jaggi RB, Weber R, Ryffel GU (1979) Vitellogenin in Xenopus laevis is encoded in a small family of genes. Cell 16:535-549

75. Felber BK, Maurhofer S, Jaggi RB, Wyler T, Wahli W, Ryffel GU, Weber R (1980) Isolation and translation in vitro of four related vitellogenin mRNAs of estrogen-stimulated Xenopus laevis. Eur J Biochem 105:17-24

76. van-het Schip FD, Samallo J, Broos J, Ophuis J, Mojet M, Gruber M, Ab G (1987) Nucleotide sequences of a chicken vitellogenin gene and derived amino acid sequence of the enclosed yolk precursor protein. J Mol Biol 196:245-260

77. Silva R, Fischer AH, Burch JB (1989) The major and minor chicken vitellogenin genes are each adjacent to partially deleted pseudogene copies of the other. Mol Cell Biol 9:3557-3562

78. LaFleur GJ Jr, Byrne BM, Kanungo J, Nelson LD, Greenberg RM, Wallace RA (1995) Fundulus heteroclitus vitellogenin: the deduced primary structure of a piscine precursor to noncrystalline, liquid-phase yolk protein. J Mol Evol 41:505-521

79. LaFleur GJ Jr, Byrne BM, Haux C, Greenberg RM, Wallace RA (1995) Liver-derived cDNAs: vitellogenins and vitelline envelope protein precursors (choriogenins). In: Goetz FW, Thomas $\mathrm{P}$ (eds) Proceedings of the fifth international symposium on the reproductive physiology of fish, University of Texas, Austin, pp 336-338

80. Reith M, Munholland J, Kelly J, Finn RN, Fyhn HJ (2001) Lipovitellins derived from two forms of vitellogenin are defferentially processed during oocyte maturation in haddock (Melanogrammus aeglefinus). J Exp Zool 291:58-67

81. Lee BH, Lim EH, Lam TJ, Ding JL (1994) Two major groups of vitellogenin cDNA clones from Oreochromis aureus (Steindachner). Biochem Mol Biol Int 34:75-83
82. Bowman CJ, Kroll KJ, Hemmer MJ, Folmer LC, Denslow ND (2000) Estrogen-induced vitellogenin mRNA and protein in sheepshead minnow (Cyprinodon variegatus). Gen Comp Endocrinol 120:300-313

83. Wang H, Yan T, Tan JTT, Gong ZA (2000) Zebrafish vitellogenin gene (vg3) encodes a novel vitellogenin without a phosvitin domain and may represent a primitive vertebrate vitellogenin gene. Gene 256:303-310

84. Trichet V, Buisine N, Mouchel N, Moran P, Pendas AM, Le Pennec JP, Wolff J (2000) Genomic analysis of the vitellogenin locus in rainbow trout (Oncorhynchus mykiss) reveals a complex history of gene amplification and retroposon activity. Mol Gen Genet 263:828-837

85. Ding JL, Hee PL, Lam TJ (1989) Two forms of vitellogenin in the plasma and gonads of male Oreochromis aureus. Comp Biochem Physiol 93B:363-370

86. Kishida M, Specker JL (1993) Vitellogenin in tilapia (Oreochromis mossambicus): induction of two forms by estradiol, quantification in plasma and characterization in oocyte extract. Fish Physiol Biochem 12:171-182

87. Shimizu M, Fujiwara Y, Fukada H, Hara A (2002) Purification and identification of a second form of vitellogenin from ascites of medaka (Oryzias latipes) treated with estrogen. J Exp Zool 293:726-735

88. Ohkubo N, Mochida K, Adachi S, Hara A, Hotta K, Nakamura Y, Matsubara T (2003) Development of enzyme-linked immunosorbent assays for two forms of vitellogenin in Japanese common goby (Acanthogobius flavimanus). Gen Comp Endocrinol 131:353-364

89. Amano H, Mochizuki M, Fujita T, Hiramatsu N, Todo T, Hara A (2010) Purification and characterization of a novel incompletetype vitellogenin protein $(\mathrm{VgC})$ in Sakhalin taimen (Hucho perryi). Comp Biochem Physiol 157A:41-48

90. Sawaguchi S, Koya Y, Yoshizaki N, Ohkubo N, Andoh T, Hiramatsu N, Sullivan CV, Hara A, Matsubara T (2005) Multiple vitellogenins (Vgs) in mosquitofish (Gambusia affinis): identification and characterization of three functional $\mathrm{Vg}$ genes and their circulating and yolk proteins products. Biol Reprod 72:1045-1060

91. Sawaguchi S, Kagawa H, Ohkubo N, Hiramatsu N, Sullivan CV, Matsubara T (2006) Molecular characterization of three forms of vitellogenin and their yolk protein products during oocyte growth and maturation in red seabream (Pagrus major), a marine teleost spawning pelagic eggs. Mol Reprod Develop 73:719-736

92. Amano H, Fujita T, Hiramatsu N, Sawaguchi S, Matsubara T, Sullivan CV, Hara A (2007) Purification of multiple vitellogenins in grey mullet (Mugil cephalus). Mar Biol 152:1215-1225

93. Finn RN, Kristoffersen BA (2007) Vertebrate vitellogenin gene duplication in relation to the " $3 \mathrm{R}$ hypothesis": correlation to the pelagic egg and the oceanic radiation of teleosts. PLoS One 2:e169

94. Williams VN, Reading BJ, Hiramatsu N, Amano H, Glassbrook N, Hara A, Sullivan CV (2014) Multiple vitellogenins and product yolk proteins in striped bass, Morone saxatilis: molecular characterization and processing during oocyte growth and maturation. Fish Physiol Bichem 40:395-415

95. Mushirobira Y, Mizuta H, Luo W, Morita Y, Sawaguchi S, Matsubara T, Hiramatsu N, Todo T, Hara A (2013) Changes in levels of dual vitellogenin transcripts and proteins in cutthroat trout Oncorhynchus clarki during ovarian development. Nippon Suisan Gakkaishi 79:175-189 (in Japanese with English abstract)

96. Wu M, Nishimiya O, Nakamori M, Soyano K, Todo T, Hara A, Hiramatsu N (2014) Molecular cloning and characterization of the expression profiles of vitellogenin transcripts in the dojo loach 
(Misgurnus anguillicaudatus) in response to $17 \alpha$-ethinylestradiol and 17ß-estradiol administration. Zool Sci 31:202-212

97. Babin PJ (2008) Conservation of a vitellogenin gene cluster in oviparous vertebrates and identification of its traces in the platypus genome. Gene 413:76-82

98. Finn RN, Kolarevic J, Kongshaug H, Nilsen F (2009) Evolution and differential expression of a vertebrate vitellogenin gene cluster. BMC Evol Biol 9:2. doi:10.1186/1471-2148-9-2

99. Fukada H, Haga A, Fujita T, Hiramatsu N, Sullivan CV, Hara A (2001) Development and validation of chemiluminescent immunoassay for vitellogenin in five salmonid species. Comp Biochem Physiol 130A:163-170

100. Hamazaki TS, Iuchi I, Yamagami K (1987) Isolation and partial characterization of a "spawning female-specific substance" in the teleost, Oryzias latipes. J Exp Zool 242:343-349

101. Murata K, Iuchi I, Yamagami K (1993) Isolation of H-SF substance, the high-molecular-weight precursors of egg envelope proteins, from the ascites accumulated in the oestrogen-treated fish, Oryzias latipes. Zygote 1:315-324

102. Shimizu M, Fujita T, Hara A (1998) Purification of the precursors to vitelline envelope proteins from serum of Sakhalin taimen, Hucho perryi. J Exp Zool 282:385-395

103. Fujita T, Shimizu M, Hiramatsu N, Fukada H, Hara A (2002) Purification of serum precursor proteins to vitelline envelope (choriogenins) in masu salmon, Oncorhynchus masou. Comp Biochem Physiol 132B:599-610

104. Fujita T, Scott AP, Katsiadaki I, Amano H, Hong L, Hiramatsu N, Todo T, Hara A (2009) Purification of multiple precursors for egg chorion proteins in Atlantic cod (Gadus morhua). Zool Sci 26:870-877

105. Hong L, Fujita T, Wada T, Amano H, Hiramatsu N, Zhang X, Todo T, Hara A (2009) Choriogenin and vitellogenin in red lip mullet (Chelon haematocheilus): purification, characterization, and evaluation as potential biomarkers for detecting estrogenic activity. Comp Biochem Physiol 149C:9-17

106. Murata K, Sasaki T, Yasumasu S, Iuchi I, Enami J, Yasumasu I, Yamagami K (1995) Cloning of cDNAs for the precursor proteins of low-molecular-weight subunit of the inner layer of the egg envelope (chorion) of the fish Oryzias latipes. Dev Biol 167:9-17

107. Murata K, Sugiyama H, Yasumasu S, Iuchi I, Yasumasu I, Yamagami K (1997) Cloning of cDNA and estrogen-induced hepatic gene expression for chriogenin $\mathrm{H}$, a precursor protein of the fish egg envelope (chorion). Proc Natl Acad Sci USA 94:2050-2055

108. Modig C, Modesto T, Canario A, Cerda J, von Hofsten J, Olsson PE (2006) Molecular characterization and expression pattern of zona pellucida proteins in gilthead seabream (Sparus aurata). Biol Reprod 75:717-725

109. Chang YS, Wang SC, Tsao CC, Huang FL (1996) Molecular cloning, structural analysis, and expression of carp ZP3 gene. Mol Reprod Dev 44:295-304

110. Chang YS, Hsu CC, Wang SC, Tsao CC, Huang FL (1997) Molecular cloning, structural analysis, and expression of carp ZP2 gene. Mol Reprod Dev 46:258-267

111. Wang H, Gong Z (1999) Characterization of two zebrafish cDNA clones encoding egg envelope proteins ZP2 and ZP3. Biochim Biophys Acta 1446:156-160

112. Kanamori A, Naruse K, Mitani H, Shima A, Hori H (2003) Genomic organization of $\mathrm{ZP}$ domain containing egg envelope genes in medaka (Oryzias latipes). Gene 305:35-45
113. Fujita T, Fukada H, Shimizu M, Hiramatsu N, Hara A (2008) Molecular cloning and characterization of three distinct choriogenins in masu salmon, Oncorhynchus masou. Mol Reprod Dev 75:1217-1228

114. Fujita T, Fukada H, Hara A (2003) Masu salmon (Oncorhynchus masou) zona pellucida protein B: cDNA cloning and tissue expression. Fish Physiol Biochem 28:333-334

115. Fujita T, Fukada H, Shimizu M, Hiramatsu N, Hara A (2004) Quantification of serum levels of precursors to vitelline envelope proteins (choriogenins) and vitellogenin in estrogen treated masu salmon, Oncorhychus masou. Gen Comp Endocrinol 136:49-57

116. Fujita T, Fukada H, Shimizu M, Hiramatsu N, Hara A (2005) Annual changes in serum levels of two choriogenins and vitellogenin in masu salmon, Oncorhynchus masou. Comp Biochem Physiol 141B:211-217

117. Williams VN, Reading BJ, Amano H, Hiramatsu N, Schilling J, Salger SA, Williams TI, Gross K, Sullivan CV (2014) Proportional accumulation of yolk proteins derived from multiple vitellogenins is precisely regulated during vitellogenesis in striped bass (Morone saxatilis). J Exp Zool 321A:301-315

118. Amano H, Fujita T, Hiramatsu N, Kagawa H, Matsubara T, Sullivan CV, Hara A (2008) Multiple vitellogenin-derived yolk proteins in gray mullet (Mugil cephalus): disparate proteolytic patterns associated with ovarian follicle maturation. Mol Reprod Dev 75:1307-1317

119. Fujita T, Fukada H, Shimizu M, Hiramatsu N, Hara A (2008) Monthly changes in the serum levels of two choriogenins and vitellogenin in male masu salmon Oncorhynchus masou. Fish Sci 74:1198-1200

120. Aoki J, Nagae M, Takao Y, Hara A, Lee YD, Yeo IK, Lim BS, Park CB, Soyano K (2010) Survey of contamination of estrogenic chemicals in Japanese and Korean coastal waters using the wild grey mullet (Mugil cephalus). Sci Total Environ 408:660-665

121. Li A, Sadasviam M, Ding JL (2003) Receptor-ligand interaction between vitellogenin receptor $(\mathrm{VtgR})$ and vitellogenin $(\mathrm{Vtg})$, implications on low density lipoprotein receptor and apolipoprotein B/E. J Biol Chem 278:2799-2806

122. Mizuta H, Luo W, Ito Y, Mushirobira Y, Todo T, Hara A, Reading BJ, Sullivan CV, Hiramatsu N (2013) Ovarian expression and localization of a vitellogenin receptor with eight ligand binding repeats in the cutthroat trout (Oncorhynchus clarki). Comp Biochem Physiol 166B:81-90

123. Reading BJ, Hiramatsu N, Sullivan CV (2011) Disparate binding of three types of vitellogenin to multiple forms of vitellogenin receptor in white perch. Biol Reprod 84:392-399

124. Reading BJ, Hiramatsu N, Schilling J, Molloy KT, Glassbrook N, Mizuta H, Luo W, Baltzegar DA, Williams VN, Todo T, Hara A, Sullivan CV (2014) Lrp13 is a novel vertebrate lipoprotein receptor that binds vitellogenins in teleost fishes. J Lipid Res 55:2287-2295

125. Ryu YW, Tanaka R, Kasahara A, Ito Y, Hiramatsu N, Todo T, Sullivan CV, Hara A (2013) Molecular cloning and transcript expression of genes encoding two types of lipoprotein lipase in the ovary of cutthroat trout, (Oncorhynchus clarki). Zool Sci $30: 224-237$ 